\title{
Quantitative Analysis of Generations for Inheritance of Fruit Yield in Watermelon
}

\author{
Rakesh Kumar ${ }^{1}$ and Todd C. Wehner \\ Department of Horticultural Science, Kilgore Hall, Box 7609, North \\ Carolina State University, Raleigh, NC 27695-7609
}

Additional index words. Citrullus lanatus, narrow-sense heritability, broad-sense heritability, effective factors, genetic gain

\begin{abstract}
There is a large genetic diversity for fruit size and yield in watermelon [Citrullus lanatus (Thunb.) Matsum. \& Nakai var. lanatus]. Current cultivars have high fruit quality but may not be the highest yielders. This study was designed to

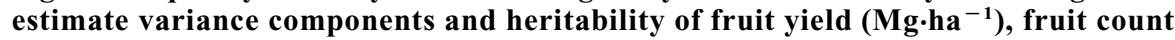
$\left(\mathrm{th} \cdot \mathrm{ha}^{-1}\right)$, and fruit size (kg/fruit) in a cross involving high-yielding 'Mountain Hoosier' with low-yielding 'Minilee'. Six generations $\left(\mathrm{P}_{\mathrm{a}} \mathrm{S}_{1}, \mathrm{P}_{\mathrm{b}} \mathrm{S}_{1}, \mathrm{~F}_{1}, \mathrm{~F}_{2}, \mathrm{BC}_{1} \mathrm{P}_{\mathrm{a}}\right.$, and $\mathrm{BC}_{1} \mathrm{P}_{\mathrm{b}}$ ) were developed and tested in Summer 2008 at two locations in North Carolina. Discrete classes were not observed within the $F_{2}$ segregating population. The actual distribution of the $F_{2}$ population for fruit yield, fruit count, and fruit size deviated from the normal distribution. 'Mountain Hoosier' had higher parental and backcross variance than 'Minilee'. High $F_{2}$ variance for fruit yield indicated large phenotypic variance. There was a larger environmental variance than genetic variance associated with the yield traits. Estimates of broad- and narrow-sense heritability were low to medium. A large number of effective factors indicated polygenic inheritance for fruit yield and fruit size. Gain from selection for yield is amendable by selection. As a result of this complex inheritance, selection based on individual plant selection in pedigree method may not be useful for yield improvement in this population. Hence, a selection scheme based on progeny testing using replicated plots, perhaps at multiple locations, is recommended.
\end{abstract}

Watermelon [Citrullus lanatus (Thunb.) Matsum. \& Nakai var. lanatus; $2 \mathrm{n}=2 \mathrm{x}=22$ ] is an economically important, cross-pollinated vegetable crop that is grown throughout the world. Watermelon is grown over 3.5 million ha worldwide with production of 104 million $\mathrm{Mg}$ (Food and Agriculture Organization, 2012). The United States is the fourth largest producer after China, Iran, and Turkey (Kumar and Wehner, 2011a). Total area has decreased from 76,000 ha in 1998 to 56,000 ha in 2011 (U.S. Department of Agriculture, 2012). However, production has increased from 1.9 million $\mathrm{Mg}$ in 1998 to 2 million $\mathrm{Mg}$ in 2011. Over $80 \%$ of production is concentrated in the southern United States where temperatures are high: Arizona, California, North Carolina, Florida, Texas, and Georgia.

Watermelon has been bred to improved fruit yield, fruit quality, disease resistance, seedlessness, short vine length, and adaptation to production areas around the world. The first genetic studies on watermelon were published in the 1930s and 1940s and involved pure-line cultivars developed in the

\footnotetext{
Received for publication 25 Mar. 2013. Accepted for publication 26 May 2013.

We gratefully acknowledge Ms. Tammy Ellington for assistance with greenhouse pollinations and field tests.

${ }^{1}$ To whom reprint requests should be addressed; e-mail rakesh.kumar@syngenta.com.
}

previous few decades. Those studies focused on traits such as rind pattern, flesh color, seedcoat color, fruit shape, fruit size, and sex expression (Poole, 1944; Poole and Grimball, 1945; Poole et al., 1941; Porter, 1933, 1937; Weetman, 1937).

Yield varies among watermelon accessions, old cultivars, and modern elite cultivars (Gusmini and Wehner, 2005). Growers are currently getting $\approx 50 \mathrm{Mg} \cdot \mathrm{ha}^{-1}$ of marketable yield (Maynard, 2001). Many have studied the inheritance of qualitative genes in watermelon (Cucurbit Gene List Committee, 1979, 1982, 1987; Guner and Wehner, 2004; Henderson, 1991; Rhodes and Dane, 1999; Rhodes and Zhang, 1995). However, there are few quantitative genetic studies, especially for important traits such as fruit yield and size. Fruit yield was reported to be correlated with component traits such as fruit count and fruit size (Kumar and Wehner, 2011b). Heterosis for watermelon fruit yield and its component traits has been reported (Brar and Sidhu, 1977; Brar and Sukhija, 1977; Chhonkar, 1977; Sidhu and Brar, 1978; Thakur and Nandpuri, 1974). However, fewer studies have examined the inheritance of fruit yield and its component traits in watermelon (Gusmini and Wehner, 2007; Kumar and Wehner, 2011a).

Gusmini and Wehner (2005) screened a diverse set of 80 watermelon cultivars for fruit yield, fruit count, and fruit size and reported a large amount of genetic variation.
Yield ranged from 114.2 Mg.ha ${ }^{-1}$ in 'Mountain Hoosier' to $36.4 \mathrm{Mg} \cdot \mathrm{ha}^{-1}$ in 'Minilee'. The highest yielders were the inbreds 'Legacy', 'Mountain Hoosier', 'Hopi Red Flesh', 'Early Arizona', 'Stone Mountain', 'AUJubilant', 'Sweetheart', 'Calhoun Gray', 'Big Crimson', 'Moon \& Stars', 'Cole Early', 'Yellow Crimson', and 'Blacklee' and the $\mathrm{F}_{1}$ hybrids 'Starbrite' and 'Stars-N-Stripes'. These high yielders included cultivars producing an intermediate number of fruit of medium size ( 9 to $12 \mathrm{~kg} /$ fruit), except 'Early Arizona', 'Stone Mountain', 'Sweetheart', and 'Cole Early', which had small (6 to $9 \mathrm{~kg}$ /fruit) fruit. 'Sweet Princess', 'Calsweet', and 'Minilee' were the lowest yielders.

To improve complex (quantitative) traits like yield, understanding variances and heritability behaviors of yield and its components is paramount. Genetic variance and heritability can be estimated using parentoffspring regression (Holland et al., 2003; Kumar and Wehner, 2011b; Nyquist, 1991), North Carolina Design I, NC Design II (Comstock and Robinson, 1948), and North Carolina Design III (Comstock and Robinson, 1952). Kumar and Wehner (2011b) used parent-offspring regression to measure heritability of yield in watermelon. However, populations that were used to calculate heritability estimates in their study were developed by half-diallel using diverse set of old and new cultivars. Those estimates were low $(0.02$ to 0.09$)$ and were applicable to those populations. That study indicated that genetic gain will be small and replicated progeny rows were required to select for yield improvement. Among other methods, a design based on the measure of variance from six generations $\left(\mathrm{P}_{\mathrm{a}} \mathrm{S}_{1}, \mathrm{P}_{\mathrm{b}} \mathrm{S}_{1}, \mathrm{~F}_{1}, \mathrm{~F}_{2}, \mathrm{BC}_{1} \mathrm{P}_{\mathrm{a}}\right.$, and $\mathrm{BC}_{1} \mathrm{P}_{\mathrm{b}}$ ) can be used to estimate environmental, genetic, additive, dominance, and phenotypic variances and heritability in biparental populations (Lyimo et al., 2011; Zalapa et al., 2006). To improve yield by pedigree selection, biparental populations can be developed by crossing high- with lowyielding cultivars. If the heritability estimates are high for yield, individual plant selection may be practiced in early generations to make genetic gain. If heritability estimates are low, selection for yield should be based on replicated plot trials at multiple locations in more advanced generations.

Genetic information related to yield improvement in watermelon is limited. The present study was designed to determine genetic variance and inheritance of fruit yield, fruit count, and fruit size from the cross of highyielding 'Mountain Hoosier' with low-yielding 'Minilee'.

\section{Materials and Methods}

Germplasm development and generation of crosses. The high yielding pure-line watermelon cultivar Mountain Hoosier (114.2 Mg.ha ${ }^{-1}$ ) was crossed to the lowyielding cultivar, Minilee (36.4 Mg.ha ${ }^{-1}$ ) (Gusmini and Wehner, 2005). In addition to fruit yield, difference for fruit size was also 
observed in 'Mountain Hoosier' $(10.2 \mathrm{~kg})$ and 'Minilee' $(3.6 \mathrm{~kg})$. Total fruit count for 'Mountain Hoosier' and 'Minilee' was 10.2 and $12.2 \mathrm{th} \cdot \mathrm{ha}^{-1}$, respectively. The population was intended for yield improvement using pedigree selection. Six generations were developed to estimate the components of variance and heritability for use in designing an optimum breeding strategy. The $\mathrm{F}_{1}$ generation was self-pollinated to produce the $F_{2}$, and $F_{1}$ generation was crossed to the high yielding parent $\left(\mathrm{P}_{\mathrm{a}} \mathrm{S}_{1}\right)$ and the low-yielding parent $\left(\mathrm{P}_{\mathrm{b}} \mathrm{S}_{1}\right)$ to produce $\mathrm{BC}_{1} \mathrm{P}_{\mathrm{a}}\left(\mathrm{F}_{1} \times \mathrm{P}_{\mathrm{a}} \mathrm{S}_{1}\right)$ and $\mathrm{BC}_{1} \mathrm{P}_{\mathrm{b}}\left(\mathrm{F}_{1} \times \mathrm{P}_{\mathrm{b}} \mathrm{S}_{1}\right)$. The six generations $\left(\mathrm{P}_{\mathrm{a}} \mathrm{S}_{1}, \mathrm{P}_{\mathrm{b}} \mathrm{S}_{1}, \mathrm{~F}_{1}, \mathrm{~F}_{2}, \mathrm{BC}_{1} \mathrm{P}_{\mathrm{a}}, \mathrm{BC}_{1} \mathrm{P}_{\mathrm{b}}\right)$ were produced in the greenhouses at the Horticultural Field Laboratory, North Carolina State University, Raleigh, NC. Parents were selfpollinated to obtain sufficient seeds for making future crosses, so they were noted as $\mathrm{P}_{\mathrm{a}} \mathrm{S}_{1}$ and $\mathrm{P}_{\mathrm{b}} \mathrm{S}_{1}$

Cultural practices. Seeds of the six generations were sown in 72-cell polyethylene flats in the greenhouse. The artificial soilless growing medium 4P Fafard soilless mix (Conrad Fafard Incorporated, Agawam, MA) was used. The medium was wetted to capacity after seeding and held in the greenhouse at 25 to $30^{\circ} \mathrm{C}$ until full emergence. The transplants were moved to a coldframe at the field site for acclimation 1 week before transplanting. The seedlings were transplanted by hand at the two-true-leaf stage. Missing or damaged transplants were replaced 1 week after transplanting. In the field, raised beds were made up with drip irrigation tubes and covered with black polyethylene mulch. The experiment was conducted using horticultural practices recommended by the North Carolina Extension Service (Sanders, 2004). To keep generations and plants separate for data collection, each plant was manually trained each week into a spiral shape by turning all the vines in a clockwise circle around the crown until fruit set. The vine training allows rapid tracing of the fruit to each plant but affects yield, so heritability estimates apply only to this method of selection (Gusmini and Wehner, 2007).

Experiment design. The field tests were conducted at two locations at the Horticultural Crops Research Station in Clinton, NC, in the summer of 2008. Two locations were designated as Clinton (M) and Clinton (P) where $\mathrm{M}$ and $\mathrm{P}$ represent blocks of the field. All six generations were planted (200 plants) at each location as follows: $\mathrm{P}_{\mathrm{a}} \mathrm{S}_{1}$ (10 plants), $\mathrm{P}_{\mathrm{b}} \mathrm{S}_{1}$ (10 plants), $\mathrm{BC}_{1} \mathrm{P}_{\mathrm{a}}$ (30 plants), $\mathrm{BC}_{1} \mathrm{P}_{\mathrm{b}}$ (30 plants), $F_{1}$ (20 plants), and $\mathrm{F}_{2}$ (100 plants). There were four rows at each location with 50 plants per row. The fields had raised shaped beds (rows) on 3.1-m centers with single hills $1.2 \mathrm{~m}$ apart.

Variances. Distributions of the $\mathrm{F}_{2}$ populations were tested for normality using ShapiroWilk's statistic (Shapiro and Wilk, 1965) in PROC UNIVARIATE procedure of SASSTAT (SAS Institute, Inc., Cary, NC) for each location. The variance components, phenotypic $(P)$, environmental $(\mathrm{E})$, genotypic $(\mathrm{G})$, and additive (A) variances, in each generation were estimated using Warner (1952) and Wright's (1968) formulae:

$$
\begin{gathered}
\sigma^{2}(\mathrm{P})=\sigma^{2}\left(\mathrm{~F}_{2}\right) \\
\sigma^{2}(\mathrm{G})=\sigma^{2}(\mathrm{P})-\sigma^{2}(\mathrm{E}) \\
\sigma^{2}(\mathrm{E})=\frac{\sigma^{2}\left(\mathrm{P}_{\mathrm{a}}\right)+\sigma^{2}\left(\mathrm{P}_{\mathrm{b}}\right)+\left[2 \sigma^{2}\left(\mathrm{~F}_{1}\right)\right]}{4} \\
\sigma^{2}(\mathrm{~A})=\left[2 \sigma^{2}\left(\mathrm{~F}_{2}\right)\right]-\left[\sigma^{2}\left(\mathrm{BC}_{1} \mathrm{P}_{\mathrm{a}}\right)\right. \\
\left.+\sigma^{2}\left(\mathrm{BC}_{1} \mathrm{P}_{\mathrm{b}}\right)\right]
\end{gathered}
$$

Negative estimates for genetic variances are possible with the experiment design adopted. Negative estimates were omitted from the tables. However, negative estimates were considered equal to zero for calculation of means (Robinson et al., 1955).

Heritability, effective factors, and genetic gain. The method used to estimate narrowsense heritability was adapted from Fehr (1991):

$$
h_{\mathrm{n}}^{2}=\sigma^{2}(\mathrm{~A}) / \sigma^{2}(\mathrm{P}),
$$

Broad-sense heritability estimates were calculated using the method described by Wright (1968).

$$
\mathrm{h}_{\mathrm{b}}^{2}=\sigma^{2}(\mathrm{G}) /\left[\sigma^{2}(\mathrm{G})+\sigma^{2}(\mathrm{E})\right]
$$

A quantitative estimate for the minimum number of effective factors (Mendelian genes or quantitative trait loci) controlling fruit yield, fruit count, and fruit size can be determined using the methods of Lande (1981), Mather and Jinks (1982), and Wright (1968). However, we have used the following method to calculate the minimum number of effective factors in this study:

Wright's method :

$\left[\mu\left(\mathrm{P}_{\mathrm{b}}\right)-\mu\left(\mathrm{P}_{\mathrm{a}}\right)\right]^{2} \times\left\{1.5-\left[2 \times \frac{\mu\left(\mathrm{F}_{1}\right)-\mu\left(\mathrm{P}_{\mathrm{a}}\right)}{\mu\left(\mathrm{P}_{\mathrm{b}}\right)-\mu\left(\mathrm{P}_{\mathrm{a}}\right)}\right.\right.$
$\times \frac{\left.\left.\mu\left(1-\frac{\mu\left(\mathrm{F}_{1}\right)-\mu\left(\mathrm{P}_{\mathrm{a}}\right)}{\mu\left(\mathrm{P}_{\mathrm{b}}\right)-\mu\left(\mathrm{P}_{\mathrm{a}}\right)}\right)\right]\right\}}{8 \times\left\{\sigma^{2}\left(\mathrm{~F}_{2}\right)-\frac{\sigma^{2}\left(\mathrm{P}_{\mathrm{a}}\right)+\sigma^{2}\left(\mathrm{P}_{\mathrm{b}}\right)+\left[2 \times \sigma^{2}\left(\mathrm{~F}_{1}\right)\right]}{4}\right\}}$

Genetic gain per cycle was measured using $\mathrm{k} \times \mathrm{h}^{2}{ }_{\mathrm{n}} \times\left[\sigma^{2}(\mathrm{P})\right]^{1 / 2}$ where $\mathrm{k}$ is selection differential. A selection differential of $5 \%$, $10 \%$, and $20 \%$ was used to calculate genetic gain per cycle.

The general assumptions for the estimation of number of effective factors (similar in concept to a gene locus) are that no linkage exists between the loci involved, the effects of all loci are equal, and all alleles for increasing the value of a trait are in a single parent and that there was no dominance and no epistasis (Wright, 1968). The presence of linkage, dominance, or unequal effects at different loci will result in an underestimation of the actual number of segregating genes present, whereas the presence of epistasis may cause either an overestimation or an underestimation of the actual number of segregating genes.

Statistical analysis of variances and heritability for fruit yield, fruit count, and fruit size was carried out using the SASQuant statistical package (Gusmini et al., 2007) for each location. Finally, data were pooled over locations. Fruit yield $\left(\mathrm{Mg} \cdot \mathrm{ha}^{-1}\right)$, fruit count (th.ha $\left.{ }^{-1}\right)$, and fruit size $(\mathrm{kg} /$ fruit) were measured in this experiment.

\section{Results and Discussion}

Test of normality. The data were analyzed using both Mendelian and quantitative approaches. In our experiments, fruit yield, fruit count, and fruit size were quantitative traits. Discrete classes were not observed within the $\mathrm{F}_{2}$ segregating population. A test of normality (Shapiro and Wilk, 1965) revealed that a normal distribution did not occur for fruit yield, fruit count, or fruit size in the $F_{2}$ population. This quantitative analysis involved calculation of genetic variance estimates, heritability, and number of effective factors (genes controlling the trait).

Yield of 'Mountain Hoosier' was higher than 'Minilee' (Table 1) at both locations. As expected, the fruit size of 'Mountain Hoosier' was larger than 'Minilee' (Gusmini and Wehner, 2005). Comparison of the $F_{1}$ mean with the parental midpoint showed dominance in the direction of higher yield and larger fruit size.

Variance components. The data were presented by location. However, to estimate variances with higher precision, data were pooled over locations. Parental variance of large-fruited 'Mountain Hoosier' was higher than that of small-fruited 'Minilee' for fruit yield, fruit count, and fruit size (Table 2). Gusmini and Wehner (2007) reported similar results for fruit size in their study. 'Mountain Hoosier' also had higher mean backcross variances for fruit yield and fruit size than 'Minilee'. High backcross variance compared with $\mathrm{F}_{2}$ variance indicated low additive variance, the portion of variance transmitted to progeny through genetic recombination As expected, the variance of the $F_{1}$ generation was low because the $F_{1}$ is a heterozygous but homogenous population. Contrary to our expectations, the parental variance of 'Mountain Hoosier' was larger than the $\mathrm{F}_{2}$ variance for fruit yield in Clinton (M). Because the $\mathrm{F}_{2}$ is the first segregating population, high variance is expected. Such results indicate high variation for measurements based on single plants. Variation in 'Mountain Hoosier', a pure-line cultivar, is all environmental $\left(\sigma_{\mathrm{E}}^{2}\right)$, whereas variation in the $\mathrm{F}_{2}$ is the result of a combination of environmental and genetic (phenotypic variance). Overall, variance for fruit yield was highest followed by fruit count and fruit size. This is indicative of large phenotypic variation for fruit yield in the population 'Mountain Hoosier' $\times$ 'Minilee'.

As expected, environmental variance was larger than genetic variance indicating quantitative rather than qualitative inheritance for fruit yield, fruit count, and fruit size (Table 3). Additive genetic variance was estimated but not dominance variance. Dominance variance could have been estimated by subtraction of genetic and additive variances from the phenotypic variance, but this estimate would be 
Table 1. Means of six generations of 'Mountain Hoosier' $\times$ 'Minilee' tested at Clinton, NC, in 2008.

\begin{tabular}{lcccccr}
\hline Trait & $\mathrm{P}_{\mathrm{a}}{ }^{\mathrm{y}}$ & $\mathrm{P}_{\mathrm{b}}{ }^{\mathrm{x}}$ & $\mathrm{F}_{1}{ }^{\mathrm{w}}$ & $\mathrm{F}_{2}{ }^{\mathrm{v}}$ & $\mathrm{BC}_{1} \mathrm{P}_{\mathrm{a}}{ }^{\mathrm{u}}$ & $\mathrm{BC}_{1} \mathrm{P}_{\mathrm{b}}{ }^{\mathrm{t}}$ \\
\hline Fruit yield (Mg.ha ${ }^{-1}$ ) & & & & & & \\
$\quad$ Clinton (M) & 32.64 & 23.11 & 39.06 & 25.01 & 52.85 & 34.47 \\
$\quad$ Clinton (P) & 46.09 & 18.83 & 26.41 & 26.00 & 25.75 & 30.73 \\
$\quad$ Mean & 39.36 & 20.97 & 32.73 & 25.51 & 39.30 & 32.60 \\
Fruit count (th.ha ${ }^{-1}$ ) & & & & & & \\
$\quad$ Clinton (M) & 4.57 & 8.34 & 5.11 & 3.71 & 5.83 & 5.38 \\
$\quad$ Clinton (P) & 7.26 & 6.72 & 4.17 & 7.34 & 3.68 & 7.35 \\
$\quad$ Mean & 5.92 & 7.53 & 4.64 & 5.53 & 4.75 & 6.37 \\
Fruit size(kg/fruit) & & & & & & \\
$\quad$ Clinton (M) & 8.50 & 2.78 & 8.32 & 8.35 & 9.98 & 7.21 \\
Clinton (P) & 7.12 & 2.91 & 7.56 & 5.22 & 7.69 & 4.88 \\
$\quad$ Mean & 7.81 & 2.85 & 7.94 & 6.57 & 8.86 & 6.09 \\
\hline
\end{tabular}

${ }^{2}$ Data are single plant measurements from 'Mountain Hoosier' $\times$ 'Minilee' from two locations at Clinton, NC.

${ }^{y} \mathrm{P}_{\mathrm{a}}=$ parental mean associated with first parent in the family.

${ }^{x} P_{b}=$ parental mean associated with second parent in the family.

${ }^{\mathrm{w}} \mathrm{F}_{1}=$ mean associated with $\mathrm{F}_{1}$ generation.

${ }^{\mathrm{v}} \mathrm{F}_{2}=$ mean associated with $\mathrm{F}_{2}$ generation.

${ }^{u} \mathrm{BC}_{1} \mathrm{P}_{\mathrm{a}}=$ backcross mean associated with first recurrent parent in the family.

${ }^{\mathrm{t}} \mathrm{BC}_{1} \mathrm{P}_{\mathrm{b}}=$ backcross mean associated with second recurrent parent in the family.

Table 2. Phenotypic variances for six generations of 'Mountain Hoosier' $\times$ 'Minilee' tested at Clinton, NC, in $2008 .^{\mathrm{z}}$

\begin{tabular}{|c|c|c|c|c|c|c|}
\hline Trait & $\sigma^{2}\left(\mathrm{P}_{\mathrm{a}}\right)^{\mathrm{y}}$ & $\sigma^{2}\left(\mathrm{P}_{\mathrm{b}}\right)^{\mathrm{x}}$ & $\sigma^{2}\left(\mathrm{~F}_{1}\right)^{\mathrm{w}}$ & $\sigma^{2}\left(\mathrm{~F}_{2}\right)^{\mathrm{v}}$ & $\sigma^{2}\left(\mathrm{BC}_{1} \mathrm{P}_{\mathrm{a}}\right)^{\mathrm{u}}$ & $\sigma^{2}\left(\mathrm{BC}_{1} \mathrm{P}_{\mathrm{b}}\right)$ \\
\hline \multicolumn{7}{|c|}{ Fruit yield $\left(\mathrm{Mg} \cdot \mathrm{ha}^{-1}\right)$} \\
\hline Clinton (M) & 426.10 & 16.61 & 45.97 & 165.40 & 56.25 & 217.12 \\
\hline Clinton (P) & 181.60 & 120.81 & 149.98 & 394.60 & 422.12 & 192.11 \\
\hline Mean & 303.84 & 68.71 & 97.97 & 280.00 & 239.18 & 204.61 \\
\hline \multicolumn{7}{|c|}{ Fruit count $\left(\right.$ th $\left.\cdot h^{-1}\right)$} \\
\hline Clinton (M) & 18.10 & 3.22 & 4.87 & 15.20 & 2.43 & 28.20 \\
\hline Clinton (P) & 8.04 & 15.40 & 4.02 & 13.00 & 5.39 & 8.42 \\
\hline Mean & 13.07 & 9.31 & 4.44 & 14.10 & 3.91 & 18.31 \\
\hline \multicolumn{7}{|c|}{ Fruit size(kg/fruit) } \\
\hline Clinton (M) & 3.52 & 0.53 & 10.48 & 6.40 & 7.33 & 4.06 \\
\hline Clinton $(\mathrm{P})$ & 13.76 & 0.11 & 9.86 & 15.63 & 19.12 & 7.56 \\
\hline Mean & 8.64 & 0.32 & 10.17 & 11.01 & 13.22 & 5.81 \\
\hline
\end{tabular}

${ }^{\mathrm{z}}$ Data are single plant measurements from 'Mountain Hoosier' $\times$ 'Minilee' from two locations at Clinton, NC. ${ }^{\mathrm{y}} \sigma^{2}\left(\mathrm{P}_{\mathrm{a}}\right)=$ parental variance associated with first parent in the family.

${ }^{\mathrm{x}} \sigma^{2}\left(\mathrm{P}_{\mathrm{b}}\right)=$ parental variance associated with second parent in the family.

${ }^{\mathrm{w}} \sigma^{2}\left(\mathrm{~F}_{1}\right)=$ variance associated with $\mathrm{F}_{1}$ generation.

${ }^{v} \sigma^{2}\left(F_{2}\right)=$ variance associated with $F_{2}$ generation

${ }^{u} \sigma^{2}\left(\mathrm{BC}_{1} \mathrm{P}_{\mathrm{a}}\right)=$ backcross variance associated with first recurrent parent in the family.

${ }^{t} \sigma^{2}\left(B_{1} P_{b}\right)=$ backcross variance associated with second recurrent parent in the family.

Table 3. Variance component and heritability estimates of 'Mountain Hoosier' $\times$ 'Minilee' tested at Clinton, $\mathrm{NC}$, in 2008. ${ }^{\mathrm{z}}$

\begin{tabular}{|c|c|c|c|c|c|c|}
\hline Trait & $\sigma^{2}(\mathrm{P})^{\mathrm{y}}$ & $\sigma^{2}(E)^{x}$ & $\sigma^{2}(G)^{\mathrm{w}}$ & $\sigma^{2}(\mathrm{~A})^{\mathrm{v}}$ & $\mathrm{h}^{2}{ }_{\mathrm{b}}{ }^{\mathrm{u}}$ & $h_{n}^{2}{ }^{t}$ \\
\hline \multicolumn{7}{|c|}{ Fruit yield $\left({\left.\mathrm{Mg} \cdot \mathrm{ha}^{-1}\right)}\right.$} \\
\hline Clinton (M) & 165.40 & 133.66 & 31.75 & 57.45 & 0.19 & 0.35 \\
\hline Clinton (P) & 394.60 & 150.59 & 244.01 & 174.96 & 0.62 & 0.44 \\
\hline Mean & 280.00 & 142.12 & 137.88 & 116.20 & 0.49 & 0.41 \\
\hline \multicolumn{7}{|c|}{ Fruit count $\left(\right.$ th $\left.\cdot h^{-1}\right)$} \\
\hline Clinton (M) & 15.20 & 7.76 & 7.46 & $\mathrm{-s}^{\mathrm{s}} \mathrm{x}-\mathrm{e}$ & 0.49 & \\
\hline Clinton (P) & 13.00 & 7.86 & 5.18 & 12.30 & 0.40 & 0.9 \\
\hline Mean & 14.10 & 7.81 & 6.32 & 6.15 & 0.44 & 0.43 \\
\hline \multicolumn{7}{|c|}{ Fruit size (kg/fruit) } \\
\hline Clinton (M) & 6.40 & 6.25 & 0.15 & 1.41 & 0.02 & 0.22 \\
\hline Clinton $(\mathrm{P})$ & 15.63 & 8.40 & 7.24 & 4.58 & 0.46 & 0.2 \\
\hline Mean & 11.01 & 7.32 & 3.70 & 3.00 & 0.33 & 0.27 \\
\hline
\end{tabular}

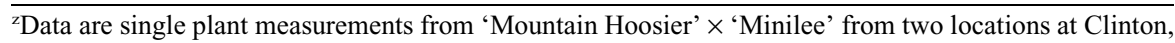
NC.

${ }^{\mathrm{y}} \sigma^{2}(\mathrm{P})=\sigma^{2}\left(\mathrm{~F}_{2}\right)=$ phenotypic variance.

${ }^{\mathrm{x}} \sigma^{2}(\mathrm{E})=\frac{\sigma^{2}\left(\mathrm{P}_{\mathrm{a}}\right)+\sigma^{2}\left(\mathrm{P}_{\mathrm{b}}\right)+\left[2 \sigma^{2}\left(\mathrm{~F}_{1}\right)\right]}{4}=$ environmental variance.

${ }^{\mathrm{w}} \sigma^{2}(\mathrm{G})=\sigma^{2}(\mathrm{P})-\sigma^{2}(\mathrm{E})=$ genetic variance.

${ }^{\mathrm{v}} \sigma^{2}(\mathrm{~A})=\left[2 \sigma^{2}\left(\mathrm{~F}_{2}\right)\right]-\left[\sigma^{2}\left(\mathrm{BC}_{1} \mathrm{P}_{\mathrm{a}}\right)+\sigma^{2}\left(\mathrm{BC}_{1} \mathrm{P}_{\mathrm{b}}\right)\right]=$ additive variance.

${ }^{\mathrm{u}} \mathrm{h}_{\mathrm{b}}^{2}=$ broad-sense heritability.

${ }^{\mathrm{t}} \mathrm{h}_{\mathrm{n}}^{2}=$ narrow-sense heritability.

${ }^{\mathrm{s}}$ Negative estimates of variance and heritability were not reported.

indirect and imprecise (Gusmini and Wehner, 2007; Kozik et al., 2013). Mean additive effects in our experiment were moderate or large for fruit yield, fruit count, and fruit size
(116.20, 12.30, and 3.00, respectively). Mean additive variance was smaller than genetic variance. A large proportion of genetic variance was additive, indicating that a major portion of the variance was heritable. Broadsense heritability was low to moderate for all traits. These results suggested that genotype accounted for $49 \%, 44 \%$, and $33 \%$ portion of total variation for fruit yield, fruit count, and fruit size, respectively. Clinton $(\mathrm{P})$ had higher estimates of additive variance and heritability for fruit yield and fruit size. Estimates of broad-sense heritability for yield, fruit number, and fruit size reported in this study are consistent with estimates reported on watermelon in previous studies (Chhonkar, 1977; Sidhu and Brar, 1978; Vashistha et al., 1983). As expected, mean narrow-sense heritability was lower than broad-sense heritability. However, it was close to the value of broad-sense heritability for fruit yield, fruit count, and fruit size ( 0.41 vs. $0.49,0.43$ vs. 0.44 , and 0.27 vs. 0.33 , respectively), suggesting that additive effects played a major role in improvement of these traits, and dominance effects were probably small. However, narrow-sense heritability was larger than broad-sense heritability in Clinton (M) for fruit yield and fruit size and fruit count in Clinton (P). Such discrepancies are possible with generation mean analysis method, which is based on single plant measurements. Larger studies using the North Carolina Design I, NC Design II (Comstock and Robinson, 1948), or North Carolina Design III (Comstock and Robinson, 1952) would provide more precise estimates of additive and dominance variance. In addition, the low to moderate heritability estimates confirm that genotype had a small to medium effect on the traits and that the traits were controlled by multiple genes. Kumar and Wehner (2011b) reported lower estimates of narrow-sense heritability. Heritability ranged 0.04 to 0.12 for fruit yield, 0.04 to 0.16 for fruit count, and 0.18 to 0.19 for fruit size. That study used parent-offspring regression and different populations for the estimates. Estimates of variances and heritability are specific to method used, environment tested, and population used.

Estimates of the minimum number of effective factors (similar in concept to gene loci) for yield traits may be biased, because we had no direct estimates of dominance effects (Kozik et al., 2013). Results showed that multiple genetic factors were involved in controlling fruit yield and fruit size (Table 4). This makes sense based on the low to moderate heritability estimates. However, fruit count showed oligogenic genetic control. Clinton $(\mathrm{P})$ and Clinton $(\mathrm{M})$ had large differences in number of genes controlling fruit yield and fruit size. Such estimates are possible with the design adopted in this experiment. Although these estimates are not precise, they support the indication of multiple loci regulating inheritance of yield traits. Our results indicating a large number of genes controlling yield agree with previous research by Zalapa et al. (2007) in melon (Cucumis melo L.). Similarly, multiple genes (more than one) controlling fruit size reported in this study are in accordance with Gusmini and Wehner (2007). 
Table 4. Estimates of number of effective factors and predicted gain from selection under different selection intensities for the 'Mountain Hoosier' × 'Minilee' population tested at Clinton, NC, in 2008. .

\begin{tabular}{|c|c|c|c|c|}
\hline Trait & Effective factors & \multicolumn{3}{|c|}{ Gain per cycle of selection $y$} \\
\hline Fruit yield $\left(\mathrm{Mg} \cdot \mathrm{ha}^{-1}\right)$ & $\mathrm{W}^{\mathrm{x}}$ & $5 \%$ & $10 \%$ & $20 \%$ \\
\hline Clinton $(\mathrm{M})$ & 13.00 & 2.40 & 2.10 & 1.70 \\
\hline Clinton $(\mathrm{P})$ & 0.10 & 13.30 & 11.40 & 9.10 \\
\hline Mean & 6.55 & 7.85 & 6.75 & 5.40 \\
\hline \multicolumn{5}{|l|}{ Fruit count $\left(\right.$ th.ha $\left.\mathrm{ha}^{-1}\right)$} \\
\hline Clinton (M) & $\mathrm{-}^{\mathrm{w}}$ & - & - & - \\
\hline Clinton $(\mathrm{P})$ & 1 & 7002 & 5982 & 4759 \\
\hline Mean & 0.50 & 3501 & 2991 & 2380 \\
\hline \multicolumn{5}{|l|}{ Fruit size (kg/fruit) } \\
\hline Clinton (M) & 23.60 & 1.10 & 1 & 0.80 \\
\hline Clinton $(\mathrm{P})$ & 0.80 & 2.40 & 2 & 1.60 \\
\hline Mean & 12.20 & 1.75 & 1.50 & 1.20 \\
\hline
\end{tabular}

${ }^{2}$ Data are single plant measurements from 'Mountain Hoosier' $\times$ 'Minilee' from two locations at Clinton, NC. ${ }^{\mathrm{y}}$ Gain per cycle of selection $=\mathrm{k} \times \mathrm{h}_{\mathrm{n}}{ }^{2} \times\left[\sigma^{2}(\mathrm{P})\right]^{1 / 2}$.

${ }^{\mathrm{x}} \mathrm{W}=$ Wright's method:

$$
\frac{\left[\mu\left(\mathrm{P}_{\mathrm{b}}\right)-\mu\left(\mathrm{P}_{\mathrm{a}}\right)\right]^{2} \times\left\{1.5-\left[2 \times \frac{\mu\left(\mathrm{F}_{1}\right)-\mu\left(\mathrm{P}_{\mathrm{a}}\right)}{\mu\left(\mathrm{P}_{\mathrm{b}}\right)-\mu\left(\mathrm{P}_{\mathrm{a}}\right)} \times\left(1-\frac{\mu\left(\mathrm{F}_{1}\right)-\mu\left(\mathrm{P}_{\mathrm{a}}\right)}{\mu\left(\mathrm{P}_{\mathrm{b}}\right)-\mu\left(\mathrm{P}_{\mathrm{a}}\right)}\right)\right]\right\}}{8 \times\left\{\sigma^{2}\left(\mathrm{~F}_{2}\right)-\frac{\sigma^{2}\left(\mathrm{P}_{\mathrm{a}}\right)+\sigma^{2}\left(\mathrm{P}_{\mathrm{b}}\right)+\left[2 \times \sigma^{2}\left(\mathrm{~F}_{1}\right)\right]}{4}\right\}}
$$

wegative estimates of effective factors and gain per cycle were not reported.

Plant breeders often use 5\% to $10 \%$ selection intensity in their breeding program, although it may be reduced to $20 \%$ or worse by simultaneous selection for multiple traits. However, it is possible to increase fruit yield, fruit count, and fruit size under those selection intensities. Selection at $20 \%$ per trait would result in a $5.4-\mathrm{Mg} \cdot \mathrm{ha}^{-1}$ gain per cycle for fruit yield and a 1.2-kg gain per cycle for fruit size.

\section{Conclusions}

Estimates of narrow-sense heritability and effective factors indicated that fruit yield, fruit count, and fruit size are quantitatively inherited traits that are amendable to selection. Based on low to medium narrow-sense heritability estimates and polygenic inheritance, it would appear that selection would be less effective in early generations of a cross. Thus, pedigree breeding would be effective if selection were practiced in late generations using replicated progeny rows. Because yield had large environmental variation, recurrent selection for population improvement should make use of family testing in replicated plots, perhaps with multiple locations.

\section{Literature Cited}

Brar, J.S. and A.S. Sidhu. 1977. Heterosis and combining ability of earliness and quality characters in watermelon [Citrullus lanatus (Thunb.) Mansf.]. J. Res. Punjab. Agr. Univ. 14:272-278.

Brar, J.S. and B.S. Sukhija. 1977. Hybrid vigor in inter-varietal crosses in watermelon [Citrullus lanatus (Thunb.) Mansf.]. Indian J. Hort. 34:277-283.

Chhonkar, V.S. 1977. Genotypic and phenotypic variability in watermelon [Citrullus lanatus (Thunb.) Mansf.]. Bangladesh Hort. 5:7-14.

Comstock, R. and H.F. Robinson. 1948. The components of genetic variance in populations of biparental progenies and their use in estimating the average degree of dominance. Biometrics 4:254-266.

Comstock, R. and H.F. Robinson. 1952. Estimating the average dominance of genes, p. 494-516.
In: Gowen, J.W. (ed.). Heterosis. Iowa State College Press, Ames, IA.

Cucurbit Gene List Committee. 1979. New genes for the Cucurbitaceae. Cucurbit Genet. Coop. Rpt. 2:49-53.

Cucurbit Gene List Committee. 1982. Update on cucurbit gene list and nomenclature rule. $\mathrm{Cu}-$ curbit Genet. Coop. Rpt. 5:62-66.

Cucurbit Gene List Committee. 1987. Gene list for watermelon. Cucurbit Genet. Coop. Rpt. 10:106-110

Fehr, W.R. 1991. Principles of cultivar development. Vol. 1. Theory and technique. McMillan, New York, NY.

Food and Agriculture Organization. 2012. FAOSTAT. 19 Apr. 2013. <http://faostat.fao. org/site/567/default.aspx\#ancor>.

Guner, N. and T.C. Wehner. 2004. The genes of watermelon. HortScience 39:1175-1182.

Gusmini, G. and T.C. Wehner. 2005. Foundations of yield improvement in watermelon. Crop Sci. 45:141-146

Gusmini, G. and T.C. Wehner. 2007. Heritability and genetic variance estimates for fruit weight in watermelon. HortScience 42:13321336.

Gusmini, G., T.C. Wehner, and S.B. Donaghy. 2007. SASQuant: A SAS software program to estimate genetic effects and heritabilities of quantitative traits in populations consisting of 6 related generations. J. Hered. 98:345-350.

Henderson, W.R. 1991. Gene list for watermelon. Cucurbit Genet. Coop. Rpt. 14:129-138.

Holland, J.B., W.E. Nyquist, and C.T. CervantesMartinez. 2003. Estimating and interpreting heritability for plant breeding: An update. Plant Breed. Rev. 22:9-112.

Kozik, E.U., U. Klosinska, A.D. Call, and T.C. Wehner. 2013. Heritability and genetic variance estimates for resistance to downy mildew in cucumber accession Ames 2354. Crop Sci. 53:177-182.

Kumar, R. and T.C. Wehner. 2011a. Breeding for high yield-A review. Cucurbit Genet. Coop. Rpt. 33/34:41-42.

Kumar, R. and T.C. Wehner. 2011b. Inheritance of fruit yield in two watermelon populations in North Carolina. Euphytica 182:275-283.

Lande, R. 1981. The minimum number of genes contributing to quantitative variation between and within populations. Genetics 99:541-553.
Lyimo, H.J.F., R.C. Pratt, and R.S.O.W. Mnyuku. 2011. Heritability and gene effect estimates for components of partial resistance to grey leaf spot of maize by generation mean analysis. Plant Breed. 130:633-639.

Mather, K. and J.L. Jinks. 1982. Biometrical genetics: The study of continuous variation. $3^{\text {rd }} \mathrm{Ed}$. Chapman and Hall, London, NY.

Maynard, D.N. 2001. Watermelons, characteristics, production, and marketing. Amer. Soc. Hort. Sci. Press, Alexandria, VA.

Nyquist, W.E. 1991. Estimation of heritability and prediction of selection response in plant populations. Crit. Rev. Plant Sci. 10:235-322.

Poole, C.F. 1944. Genetics of cultivated cucurbits. J. Hered. 35:122-128.

Poole, C.F. and P.C. Grimball. 1945. Interaction of sex, shape, and weight genes in watermelon. J. Agr. Res. 71:533-552.

Poole, C.F., P.C. Grimball, and D.R. Porter. 1941 Inheritance of seed characters in watermelon. J. Agr. Res. 63:433-456.

Porter, D.R. 1933. Watermelon breeding. Hilgardia 7:585-624.

Porter, D.R. 1937. Inheritance of certain fruit and seed characters in watermelons. Hilgardia 10: 489-509.

Rhodes, B. and F. Dane. 1999. Gene list for watermelon. Cucurbit Genet. Coop. Rpt. 22:61-77.

Rhodes, B. and X. Zhang. 1995. Gene list for watermelon. Cucurbit Genet. Coop. Rpt. 18: 69-84.

Robinson, H.F., R.E. Comstock, and P.H. Harvey. 1955. Genetic variances in open pollinated varieties of corn. Genetics 40:45-60.

Sanders, D.C. 2004. Vegetable crop guidelines for the southeastern U.S. North Carolina Veg. Growers Assn., Raleigh, NC.

Shapiro, S.S. and M.B. Wilk. 1965. An analysis of variance test for normality (completed samples). Biometrika 52:591-611.

Sidhu, A.S. and J.S. Brar. 1978. A note on genotypic and phenotypic variability of some important quantitative characters in watermelon [Citrullus lanatus (Thunb.) Mansf.]. Haryana J. Hort. Sci. 7:208-210.

Thakur, J.C. and K.S. Nandpuri. 1974. Studies on variability and heritability of some important quantitative characters in watermelon [Citrullus lanatus (Thunb.) Mansf.]. Veg. Sci. $1: 1-8$.

U.S. Department of Agriculture. 2012. Agricultural statistics for 2011. U.S. Dept. Agr., Washington, DC

Vashistha, R.N., P.S. Pratap, and M.L. Pandita. 1983. Studies on variability and heritability in watermelon [Citrullus lanatus (Thunb.) Mansf.]. Haryana Agr. Univ. J. Res. 12:319-324.

Warner, J.N. 1952. A method for estimating heritability. Agron. J. 44:427-430.

Weetman, L.M. 1937. Inheritance and correlation of shape, size, and color in watermelon, Citrullus vulgaris Schrad. Iowa Agr. Expt. Sta. Annu. Bul. 228:224-256.

Wright, S. 1968. The genetics of quantitative variability, p. 373-420. In: Wright, S. (ed.). Evolution and genetics of populations. Univ. Chicago Press, Chicago, IL.

Zalapa, J.E., J.E. Staub, and J.D. McCreight. 2006 Generation means analysis of plant architectural traits and fruit yield in melon. Plant Breed. $125: 482-487$

Zalapa, J.E., J.E. Staub, J. McCreight, S.M. Chung, and H. Cuevas. 2007. Detection of QTL for yield-related traits using recombinant inbred lines derived from exotic and elite U.S. western shipping melon germplasm. Theor. Appl. Genet. 114:1185-1201. 